\title{
Just Laws versus Unjust Laws: Asserting the Morality of Civil Disobedience
}

\author{
Amin George Forji \\ Faculty of Law, Department of Public Law, University of Helsinki \\ E-mail: amingeorges@yahoo.co.uk
}

\begin{abstract}
How is a citizen living under a merciless totalitarianism such as the Nazi but opposed to its philosophies expected to respond to the law? Where does his primary obligation as a citizen reside? Is it to the laws of the land that command total submission or to his convictions by which he is convinced that the system is totally unjust? Does one have a moral obligation to always obey the law? Conversely, should one obey an unjust law? Obviously, such an individual like Antigone in ancient Greece is naturally torn between two loyalties. (Note 1)If he obeys the law, he would be guilty of knowingly aiding to sustain an unjust system. If he follows his moral judgment and violate the law, he would be charged with the penalty stipulated in the law.
\end{abstract}

Keywords: Just Laws, Unjust Laws, Civil Disobedience

\section{Introduction}

It is heartbreaking to read about Hitler's atrocious reign in Germany. Nazism had a strict hierarchical classification of the human race with the Aryan people or master race (white European origin) at the top and Untermenschen or sub humans (non-Aryan/white European origin) at the lowest level. (Note 2)The Untermenschen were inferior and seen as dangerous to the society. The killing of Jews, Gypsies, people with disabilities, Jehovah Witnesses, homosexuals, etc was according to this philosophy in line with Rassenhygiene or racial hygiene, thus justified because it purportedly eliminated danger, the mentally ill and the disabled thus sparring state institutions huge maintenance costs.(Note 3) This may all sound perplexing to us today, yet, interestingly, "everything Adolf Hitler did in Germany was 'legal' and everything the Hungarian freedom fighters did in Hungary was 'illegal'.'(Note 4) It was also 'illegal' to aid and comfort a Jew in Hitler's Germany. (Note 5)

How is a citizen living under a merciless totalitarianism such as the Nazi but opposed to its philosophies expected to respond to the law? Where does his primary obligation as a citizen reside? Is it to the laws of the land that command total submission or to his convictions by which he is convinced that the system is totally unjust? Does one have a moral obligation to always obey the law? Conversely, should one obey an unjust law? Obviously, such an individual like Antigone in ancient Greece is naturally torn between two loyalties.(Note 6) If he obeys the law, he would be guilty of knowingly aiding to sustain an unjust system. If he follows his moral judgment and violate the law, he would be charged with the penalty stipulated in the law.

Given that the resolution of every problem requires first that the problem be understood, I will begin by briefly highlighting some historical instances of civil disobedience that will form the basis of this paper. Antigone's beloved brother was charged by Creon the king with treason. According to law, his corpse as punishment was to be left in the open, unburied, outside the city walls for eagles, dogs and vultures to eat it. She was required by her religion on the other hand to bury and mourn her dead brother. (Note 7) Upon consideration, she chose to follow her conscience and pay the penalty with her life. Conversely, Adolf Eichmann, an extremely submissive Second World War German veteran so "conform[ed] to the law as to compromise the individual's responsibility for developing and living in a way consonant with truth, justice, and love for fellow man." (Note 8) Socrates defiled the law and exercised his professed "freedom of speech." He peacefully accepted to drink the poison as required by the laws of Athens. (Note 9)

Gandhi inspired a large-scale resistance against the British colonial rule in India, because the latter unjustly "maintained a ruinously costly civil and military administration, destroyed indigenous industries and de-industrialised India, ignored its agricultural development, caused massive unemployment and famine and in general exploited it." (Note 10) Moreover, the British "sapped the foundations of Indian civilization, de-nationalised the Indians, ridiculed their society and religion, and foisted their values on them." (Note 11)

In United States of America (USA), the segregation laws called Jim Crow laws decreed a society of "separate but equal" services for whites and coloured peoples. In reality, this was not an arrangement of racial separation but instead a system of white supremacy, secured by terror. (Note 12) Civil rights activists such as martin Luther 
King Jr. and Malcolm X engaged the so-called American Negroes in various campaigns of civil disobedience, albeit with different orientations. Decades earlier, even before King and Malcolm X, Thoreau(Note 13) had refused to pay the Massachusetts poll tax in protest of the government's support of chattel slavery and its invasion of Mexico. Taxes in his opinion were illegally and immorally imposed in order to assist the enforcement of these acts. (Note 14)

To say the least thus, the question whether one is bound to always obey the law is increasingly important during periods of grossly immoral legislations and unjust institutions. (Note 15) The law is a teacher and its supposed utility is to the greatest good. Just as street signs guide all cars and pedestrians on the highway to drive or walk in a particular direction, the law has a corresponding responsibility to walk the society towards a path of equity. But law in itself does not mark the end of the road. It only points the way to justice. (Note 16) My contention in this paper is that in cases of gross immorality, illegality and disregard to the tenets of fairness, the law cannot be perceived as acting as a teacher.

\section{What Civil Disobedience Is and What It Is Not}

A simplistic definition of civil disobedience provides that it is an "illegal activity undertaken to protest laws that are regarded as unjust." (Note 17) The act usually takes the form of a "deliberate and open violation of law with the intent, within the framework of the prevailing form of government, to protest a wrong or to accomplish some betterment in the society." (Note 18) The purpose is to purify the legal system of "unjust laws and practices." (Note 19) The violations have the effect of creating a tension as well as forcing a community that has constantly refused to negotiate to finally confront the issues. (Note 20) It is an open defiance of the law irrespective of whether the act itself will be vindicated through the legal system. (Note 21) By dramatizing the issue, public attention is drawn to the alleged injustice, such that it can no longer be ignored. (Note 22) Thus, the open nature of the violation is an invitation for others to join in such violation. (Note 23) Another reason for the openness of the act is based on the fact that the dissenters' main interest is to see a change in an unjust institution. They see their violation as a civic act that properly fit into the public life of the community; or as acting to help thwart some laws or policies that have deviated from the true purpose of government. (Note 24)

The openness of the violation for the most part is a tactic in itself, given that a stimulated public sentiment may just be everything they need. Bad laws would eventually lose their influence hence injustice prevented from occuring where the hearts and minds of people are changed against them. King was quickly bailed out of Birmingham jail (even without applying for one) because the authorities feared the publicity that his arrest was generating. (Note 25) Persuation although far from being an exclusive method is considered to be a very effective means of civil disobedience. Abraham Lincoln once remarked that "with public sentiment, nothing can fail, without it, nothing can succeed. Consequently, he who moulds public sentiment goes deeper than he who enacts statutes or pronounces decisions. He makes statutes and decisions possible or impossible to be executed." (Note 26) It is therefore important to the dissenters that both the public and the government know of their act, because at the end of the day, it is the government that would change the challenged policies or laws. (Note 27) Public sympathy would evidently be useful in precipitating this occurrence.

Civil disobedience is different from evasion of law. Unlike the civil disobedient, the law evader attempts to conceal his violation and the penalties of the law. A good example of a law evader is the case of a militia or mafia that musters and hoards enough weapons to overpower agencies of law enforcement, and elude punishment by carrying out unauthorized activities. (Note 28) A traffic violator who tries to dodge and do away with his crime is also an evader and not a civil disobedient. The Law evader does not at all think of himself as committing an act of civil disobedience. Evasion of the law is however not always wrong. Take for instance the case of a citizen who violates the apartheid decrees in South Africa, Nazism in Germany or the American Fugitive Slave Act of 1850. Today, we can concur that such violations were warranted. Most importantly, protesters engaged in civil disobedience strongly nurse the conviction that a specific law is illegal, unconstitutional or unjust. They thus deliberately violate it as an effective way of getting it declared illegal. (Note 29) Civil disobedience however excludes people who unconsciously violate an unjust law.

\section{Framing the Inquiry}

This paper critically explores the dilemmas facing the legal order when individuals deliberately violate the law because it conflicts with their good conscience. The debate over the justification of civil disobedience specifically rests on the conflict between those postulating an absolute submission to the law at all times (whether or not these laws are just or unjust) and those postulating obedience to the law only if it is sufficiently backed by a moral condition. Looking back, violations seem today to have been warranted by Antigone, Socrates, 
Eichmann, or a dissenting citizen who lived in atrocious Nazi Germany, Apartheid South Africa, Jim Crow America or colonized Africa.

My purpose is however not to devise a general theory of moral responsibility as such, but instead to articulate various scenarios under which resort to civil disobedience can be justified. Even here, I will shy away from suggesting any hard and fast rule given that the categories of rights violation and lawlessness can never be closed, nor are they calculable by any simple formula. The attributes of justice are a subject on which philosophers and scholars constantly disagree about its true nature.(Note 30) The same goes for the scope of civil disobedience.

Thoreau, Gandhi and King are very closely related with the concept of civil disobedience as used in everyday speech. (Note 31) Amongst the many attributes they shared in common, they all strongly believed that their systems were unjust and required fundamental transformation. Neither did they think there was any moral obligation for them to observe unjust laws. As a result, they were prepared to accept the legal penalties that accompanied their violations. (Note 32) Gandhi and King especially advocated for non-violence direct action as a means of resisting unjust laws. Many authors have since restricted their analysis of civil disobedience to "nonviolent" protests. (Note 33) This paper considers such an assumption to be as pretentious as its imprecision. There is no convincing basis for the restriction to just this one species of principled resistance. (Note 34) Their resort to nonviolence reflected their moral and religious judgments, but clearly not the end of the road on the subject.

Despite the unquestionable relevance of Thoreau, Gandhi and King, it would be an academic scandal to discredit or take no notice of the immense contributions of historical movements and figures such as nationalist struggles, freedom fighters, Che Guevara, Malcolm X and Nelson Mandela, all of whom advocated for other methods other than nonviolence (mostly to a successful degree) to also thwart the unjust laws and policies in their systems. The USA is an example of a country that was founded on rebellion. It wasn't nonviolent, yet it liberated the West Indies from British colonization. The same is true for all those heroes who revolted against chartered slavery, imperialism and segregation statutes. In a nutshell, civil disobedience is still a concept in search of limits. (Note 35) Dissenters have been an invaluable feature of many constructive revolutions in human history. Apartheid in South Africa was cruised through the peoples' revolt; the colonized peoples of Africa, Asia and Latin America were liberated through rebellions, etc. Civil disobedience is a useful and necessary purpose to induce change in an unjust society where traditional means are inadequate, unable or unwilling to correct a brutally unjust system. (Note 36)

\section{Social Contract Theory}

The history of the world from the perspective of Social Contract theorists can be divided into two clear periods to wit: the period before and the period after the state. In the first period, there is no government or law (state of nature). In the second, there is a contract between the subjects in nature (that is, the government and the people). According to John Locke, the raison-d'être of establishing a government was to move men away from a state of nature, given that men in the state of nature were too often judges in their own cases. A civil society was vital to guarantee peace and a common judge to settle disputes for everyone. The constitution and institutions of government are in place to ensure that individuals conform to the dictates of reason and justice since "the passions of men will not conform to the dictates of reason and justice, without constraint".(Note 40)

The Social Contract theorists thus supposedly shared a radically democratic understanding of "the people" that constituted the contractual relationship. (Note 41) Any disconnect in that relationship has been mirrored with qualified adjectives such as "invasion of rights", "usurpation", "and betrayal of trust", "mutual covenant", "and state of nature", "social contract and the dissolution of government". (Note 42) Thomas Hobbes contended that the sovereigns were the beneficiaries of the "contractual authorization", while John Locke added that the nature of the relationship between the sovereign and the people was one of trust not contract. (Note 43) Moreover, Locke contended that the fundamental rights actually belonged to man by nature and the state was credited with a trust that these rights shall not be taken away, and if the rulers committed a breach of trust, then the people were justified to take away the powers from the ruler. (Note 44)

The significance of this theory lies in its assumption that the civil society is based on consent. It instills the view that the state is a "contractual" servant and not the master of the people. The contract is only valid for as long as the state honours its servitude to the people. Consequently, whenever any form of government becomes vi cious (betrayal of trust), it is the right of the people in the interest of the society to take back the power they have entrusted on it. 
The ideals of democracy are very closely related with the basic fundamentals of the social contract theory. A democracy to quote its founding father, Abraham Lincoln, is a "government of the people, by the people and for the people." (Note 45) A democratic regime as a result gets its governing mandate from a majority of the populace through a free and fair election. By casting their ballots or votes, the citizens are in effect expressing their consent to the authority of the winning majority to legitimately act on behalf. It follows that an administrator is stricto sensu a servant assigned to manage something in the interest of the community. (Note 46) Characteristically, a democratic culture emphasizes participation of all citizens, observance of the rule of law, equality of all citizens, right to assemble, education, the building of self confidence and a sense of somebodiness.

The above characteristics presuppose that the people that must obey the law in a democracy have naturally been consulted, and have the legal channels through which they could express their protests and to work for reform. (Note 47) If the regime vitiates their consent or fail to recognize the basic rights of everyone in the society including the minority, such a regime can be said to be undemocratic, because it has betrayed the trust that the people collectively bestowed on it. (Note 48) Such is the case with an administration with a reputation of bad faith, manipulations and dishonesty of those or a cross section of those it administers. It is not uncommon to witness a situation in which administrative officials mistake between God and themselves, are dictatorial and arrogant, serve their own personal interests instead of that of the community. (Note 49) In a political system that is democratic, we expect to see an administration that is responsive to the needs of the citizens, is accountable to the people who in turn can democratically elect and fire any administration as they please. (Note 50)

There seems to be a good deal of distress amongst scholars regarding the upsetting paradox of American democracy throughout the $19^{\text {th }}$ century and first half of the $20^{\text {th }}$ century. Although America has always been regarded as the undisputed seat of democracy, it is anything but shameful and embarrassing that for so long it preached one thing to the world only to turn around and practice the opposite. All agencies of administration brutally sanctified a society of free persons and slaves. To quote one scholar, "[Citizenship in] America has in principle always been democratic, but only in principle. From the first the most radical claims for freedom and political equality were played out in counterpoint to chattel slavery, the most extreme form of servitude, the consequences of which still haunt us." (Note 51) She was referring to the frustrating denial of basic rights to blacks or so-called Negroes living in a country that relentlessly professed to be the powerhouse of democracy.

The paradox of American hypocrisy is even more disturbing when we consider the basic principles on which its "democratic" institutions were built on. When the forefathers of American independence threw off their allegiance to Great Britain, one observer has pointed out, they "founded a republic of the United States, they announced to the world certain political ideas, all of which they firmly believed, but very few of which they ventured to put in practice." (Note 52) "They declared that all men are created equal, and endowed by their creator with the inalienable rights of life, liberty, and the pursuit of happiness, that government is constituted amongst men for the sole purpose of securing these rights, that it derives its just powers from the consent of the governed, and that, failing to accomplish the high purpose for which it is established, it becomes the duty of the people to alter or destroy it." (Note 53)

On the one hand, the US government alleged to be committed to the rule of law. In practice however, she sanctioned the brutal, systematic denial of civil rights to African Americans. (Note 54) Local officials were indifferent to the state of injustice and would rarely interfere with, no less prosecute violence against Blacks; instead, they were frequently involved in many of the discriminatory atrocities. Neither was there any determined interference from the federal government. Faced with perpetual prejudice, the rule of law became a false promise to most African-Americans. (Note 55)

\section{The Case for Civil Disobedience}

The concept of civil disobedience confronts us with a paradox as it calls for the open violation of a given law. Going back to the citizen torn between two loyalties, notably the law and his conscience, two conflicting schools of thought have afforded different answers to the problem. One is to the effect that civil disobedience is incompatible with legal institutions, and that obedience to the law is a civic obligation, until such a time when the law is changed by an appropriate constitutional process. The other asserts that only just laws should be obeyed. Although both assertions have plausible claims, I argue that a rigid supposition of civic obligation to always obey the law is morally flawed.

Let me begin the section by examining the claim postulating for an absolute obligation to always obey the law. It has been observed and rightly too that the law can never make provision for its violation except to hold the offender liable for punishment. (Note 56) In other words, it is not possible to have a law to which obedience is optional. (Note 57) To this effect, one proponent has advanced four considerations to justify a supposedly 
political obligation to obey all laws, irrespective of whether they are just or unjust, namely: "(a) disobedience undermines public order; (b) there is an implied contract to obey the laws, just or unjust; (C) there is a debt due the state that can only be met by obedience, and (d) if the state offers opportunity to be convinced of its wrong and one fails, he should obey." (Note 58)

Advocates of a political obligation to obey all laws sometimes anchor their base on Socrates' refusal to flee the Athenian prison into exile, even when an opportunity reportedly emerged to do so. (Note 59) Instead, he submitted himself to the fate of Athenian law by drinking poison. This is at best a controversial argument, considering that when Socrates in defiance of the law continued to exercise his professed right to free speech, he was by so doing actually practicing civil disobedience. His paradoxical adherence to laws that he so fervently opposed can be understood in the light of his conviction that the needed change would be accomplished only by working through the system. By all intents and purposes, the contention of advocates of political obligation is that no legal system can carry on where each individual is free to pick and chose which laws to obey and which to disobey. Were this to be the case, the result may be violence, chaos or a total breakdown of the rule of law.(Note 60) Let me also point out that there is usually just as much a strong argument for total submission to laws in a "democracy" as it is in a tyranny. For the most part, the claims tend to be as pretentious as they are misleading. Let's take for illustration the interpretation of the democratic concept of majority rule by one of such arguments: "[The concept of democracy rests on the assumption that] 'almost without exception individuals will accept the will of the majority even when to do so is grudging and distasteful'..." (Note 61)

The above claim represents a distorted conception of a democratic majority. As noted before, a democratic culture is one that besides ensuring a free and fair election for all eligible voters emphasizes participation, observance of the rule of law, equality of all citizens, right to assemble, education, the building of self confidence and a sense of somebodiness. It is not enough to have a majority. It must be backed by a just, democratic institutional process. Even though all democratic regimes come to the office through a majority, not all majority rule are however democratic.

This leads us to the second arm of the debate namely that only just laws should be obeyed. As we have just seen, there can be a very sound argument for a political obligation to always obey the law. However, those same arguments can become victims of their own very postulations, because law is not absolute. The rigorous character of a democratic culture implies that law is only supreme for as long as it is just, grounded on rules of fair play and not contrary to good faith. Just laws merit respect. The reverse is true of unjust laws. (Note 62) It is also not enough to preach principles. They must be backed by a committed intent to enforce them. Although President Kennedy often expressed signs of sympathy from the sidelines to the "Negro" demonstrations, he nevertheless came under fierce criticism from civil rights activists for his inactions. (Note 63) "The betterment of a society is first and foremost an ethical venture, and "ethical conduct is above all a practical affair. It requires not only meaning well but also doing well." (Note 64)

Lets reconsider the examples of Nazi Germany, Apartheid South Africa, Jim Crow America, all of which openly discriminated and excluded a significant portion of the population from the political process based on race. Because of these exclusions, the majority rule (or minority rule in the case of South Africa) was undemocratic in practical sense. Not only were they authoritarian, they also sustained their rule by acts unworthy of a democratic culture. However stable and effective a majority rule, there can never be a democratic right to commit torture, genocide, holocaust, racism, segregation, etc. These acts are by their very nature, atrocious and contrary to the spirit of rule of law or democratic values. In such regimes, the duty to always comply with the law is obviously problematic for minorities who have never known anything else but injustice.

Civil disobedience is a direct challenge to the notion that a majority is always right, and as a consequence the minority must accept their will. There is a gist of truth in the assertion though, in that a democratic government once elected governs on behalf of all citizens, including those who voted against it. (Note 65) It would be unrealistic to expect every governmental decision to win the unanimity or approval of all the populace. Thomas Jefferson in his inaugural address of 1801 laid down an unqualified obligation to submit to the decisions of the majority, for as he put it: "absolute acquiescence in the decisions of the majority [is]-the vital principle of republics, from which there is no appeal but to force..."(Note 66) A similar insistence on political obligation to laws at all cost was later adopted by Charles Evans Whittaker, the former conservative US Supreme Court Justice who blasted the civil rights movement thus:

While I do not claim that all of our crime is due to any one cause, it seems rather clear that a large part of the current rage and rapid spread of lawlessness in our land has been at least, fostered and inflamed by the preachments of self appointed leaders of minority groups to 'obey the good laws, but to violate the bad ones' 
-which, of course, simply advocates violation of laws they do not like, or, in other words, the taking of laws into their own hands. (Note 67)

The above arguments are clearly misguided given that they not only silence the minority voice but also raise those in power to a status equal to or above the law. They are passionate adherents of majority rule, but not necessarily a democratic rule nor the rule of law or equity. Moreover, it is at best controversial who is actually showing greater respect for the law-justice. Is it the civil disobedient who is committed to get rid of an unjust system or the segregationist who through cruel deliberate tactics enslaves and torment other members of his society. I submit that the segregationist actually poses the most threat the law because unlike the civil disobedient, the last thing he wants in his society is justice. Abraham Lincoln adopted a more modest position, even offering some soft support for civil disobedience when he addressed the same issue some three decades after Jefferson, before the Young Men's Lyceum of Springfield, Illinois:

"...Let every man remember that to violate the law is to trample on the blood of his father, and to tear the charter of his own and his children's liberty...And in short, let it become the political religion of the nation... When I so pressingly urge a strict observance of all the laws, let me not be understood as saying there are no bad laws, or that grievances may not arise for the redress of which no legal provisions have been made. I mean to say no such thing. But I do mean to say that although bad laws, if they exist, should be repealed as soon as possible, still, while they continue in force, for the sake of example they should be religiously observed..."(Note 68)

Their variations notwithstanding, the pronouncements of Jefferson, Whittaker and Lincoln nonetheless have a common denominator which is the insistence on the fact that chaos would reign if every citizen is allowed to pick and choose what laws to obey and what to disobey. A parallel argument can be advanced that discrimination inevitably breeds chaos. Civil disobedience is warranted for a society that is so sick with injustice and law enforcement is deliberately poor---one that arbitrarily picks and chooses which citizens to benefit from the national cake, and which to be sidelined. Protest movements necessarily reflect crises in law enforcement. (Note 69) Racial disharmony undoubtedly threatens many institutions. (Note 70) King famously observed that injustice anywhere is a threat to justice everywhere. (Note 71) Far from the assertions of Jefferson and Whittaker, an act of civil disobedience does not cast doubt on one's patriotism or even respect to the law. Instead, where the act is fittingly justified, it rather strengthens and reaffirms the principles of democratic governance upon which a free society is based. (Note 72) Anyone who does not agree at this point that laws can sometimes be blatantly unjust would as well find absolutely nothing absurd about the cruelty of the Nazi regime.

It is also imperative to understand the philosophy and techniques of those challenging the law. Perhaps the most eloquent basis for civil disobedience has been advanced by King and Malcolm X. Let me begin with King. In his Letter From only put forward a sharp condemnation of Jim Crow but moreover advanced a strong moral justification for disobeying unjust laws:

"An Individual who breaks a law that conscience tells him is unjust, and willingly accepts the penalty...to arouse the conscience of the community over its injustice, is in reality expressing the very highest respect for the law...It was 'illegal' to aid and comfort a Jew in Hitler's Germany. But I am sure that if I had lived in Germany during that time I would have ...comforted...the Jewish people.” (Note 73)

King went on to suggest four necessary steps or requirements which he supposed should be at the basis of every civil disobedience. The first step is the collection of facts to determine whether injustice exists. The next steps involve negotiation; self-purification and direct action. He observed that blacks had gone through all those steps in Birmingham.(Note 74) In addition, King asserted, civil disobedients should demonstrate their respect for the legal order in place by breaking the law openly, lovingly and with the willingness to accept the penalty.(Note 75) King's philosophy perceives laws not as ends in themselves but rather means of achieving justice. (Note 76)

In order to buttress his proposition, he offers three definitions of just and unjust laws. First, he asserted, "a Just law is a man-made code that squares with the moral law or the law of God. An unjust law is a code that is out of harmony with the moral law." (Note 77) Secondly, "an unjust law is any law forced on a minority not followed also by the majority. And third, an unjust law is any law that a minority had no voice in making." (Note 78) There could actually be as many definitions of just and unjust laws as there writers on the subject. Whichever way we look at it, there can be no denying the fact that segregation, Aryan and apartheid laws are unjust by all counts. There can also be no denying the fact that any law construed with bad faith is bad law. In line with Saint Augustine who posited that "an unjust law is no law at all", King arrived at a parallel conclusion that one has a moral responsibility to disobey unjust laws. (Note 79)

Apparently, there was no limit to King's nonviolence philosophy in conflict situations. (Note 80) Its persuasion and moral vigor notwithstanding, King's philosophy would be unrealistic in every circumstance if not most 
situations. It fuels the desired pressure against a prevailing state of injustice but does very little to prevent the actual commission of evil. A nonviolent movement could not have halted Hitler's army or evil ambitions. (Note 81) In fact, even until this day, the concepts of violence and nonviolence are still hotly debated topics. Each of them, if well-grounded can serve as an anchor to any civil disobedience campaign. Nothing in the philosophy of civil disobedience precludes resort to violence, if it is deemed as the only means to bring about a just society. (Note 82)

Malcolm X, another prominent civil rights activist against Jim Crow for instance rejected the nonviolent philosophy as an "uncle Tom" philosophy of a fool, opting for a more involved position. In direct contrast to King and his nonviolent philosophy, Malcolm X conceived retaliatory violence or self defense as a necessary response to criminal acts of whites on blacks. (Note 83) At the widely televised Oxford Union debate in 1964, Malcolm X argued in favour of the proposition that extremism in defense of liberty is no vice, and moderation in the pursuit of justice is no virtue. (Note 84)

Malcolm X did not expressly advocate for violence; he mainly justified the right of self defense. Indeed, in the course of the Oxford debate, he insisted that he did not believe in any form of extremism. He nevertheless recognised that when a man is exercising extremism in the defense of liberty for human beings that cannot be considered to be a vice. By the same token, if a man is moderate in defense of justice for human beings, then that individual is equivalent to a sinner or a coward.(Note 85) The lives of blacks were dire and pathetic caused by centuries of white racism, segregation and discrimination. As Malcolm X also pointed out, the American government and all its agencies of law enforcement were indifferent, hypocritical, direct or indirect co-conspirators to white supremacy groups committing unspeakable atrocities on blacks. Blacks in America, he contended were faced with a racialistic society, a society which at every echelon was both deceitful and deceptive. Contrary to King, Malcolm X saw the eye-for-an-eye principle as a necessary and most effective means to bring about the much needed change. That is, speaking the same language so that the racialist could understand. The whole talk of nonviolence was an alien language to the violent racialists in the same way that French, Finnish, Arabic, Russian, German or Swahili is foreign to an American.

Moderate whites admonishing blacks to stick to the nonviolent campaign in order to gain their civil rights were wretched hypocrites because of the contradiction with how they acted when whites felt that their rights had been violated. They do not "advocate turning the other cheek or kneeling down to pray. Because whites did not apply to themselves the same moral logic they urged upon blacks, Malcolm regarded them as the worst hypocrites on the planet" (Note 86). Whites, Malcolm observed recognized self-defense as an inherent right, but not for blacks. (Note 87) What is good for the goose is surely good for the gander. If whites had a right to defend themselves against their enemies, the same could be expected from blacks. It is important that a civil disobedient movement employs maximum care in order to avoid a state of lawlessness or an anarchical situation that may diminish its usefulness. After all, its primordial goal is to attain a positive action to better both the law and its enforcement. (Note 88) Even though it may be a sane thing for a civil disobedience movement to stay as nonviolent as possible, it must also be observed that they naturally retain an inherent right of self defense.

Malcolm X did not think the problem was one of lack of laws but rather the unwillingness to enforce the laws or commit to justice. Blacks were at the mouth of the whites' hitting hammer. It is they (blacks) who had their skulls crushed, not only by the ku klux klan, but also by policeman, all because they wanted to have the laws enforced. They were accustomed to having water-hoses turned on their backs, practically so hard that it ripped off their clothes, etc. (Note 89) Malcolm also observed that blacks like Hamlet in William Shakespeare were faced by the dilemma "whether it was nobler in the mind of man to suffer the slings and arrows of outrageous fortune in moderation, or to take arms against a sea of troubles and by opposing end them" to which he laid a classic caveat at the Oxford debate to thunderous applause that "any time you live in a society supposedly based upon laws and it doesn't enforce its own law because the color of a man's skin happens to be wrong, then I say those people are justified to resort to any means necessary to bring about justice where the government can't give them justice." (Note 90)

We have just seen how King and Malcolm X approached civil disobedience from two contrasting dimensions. My interest here is not to adopt one of these approaches over the other but rather to illustrate the deficiencies and in-exhaustiveness of studies that have restricted their analysis of civil disobedience to "nonviolent" protests. (Note 91) Whichever way we appreciate the philosophies of king and Malcolm X, there can be no denying the fact that it is their combined revolutionary tactics that immensely contributed to the final tearing down of the ugly Jim Crow curtains across America. The deconstruction of their varying philosophies has demonstrated that the decision to result to civil disobedience is a composite judgment that cannot be calculable by one single formula. Not even Thoreau, generally recognized as one of the forerunners in the discipline attached any 
stringent nonviolent character to it. Victims of oppression or an unjust system are free to employ different means in order to bring about lasting justice. It can be directly or indirectly. For instance, it may be directly as in the case of violating an objectionable law and indirectly by violating some other law. (Note 92)

Another drawback of studies that approach civil disobedience solely from a nonviolent perspective is their insistence that the violator must gracefully accept punishment. The refusal of Socrates to flee the Athenian jail and King's Letter From Birmingham Jail are the two main grounds on which such arguments are anchored. (Note 93) These arguments are anything but an over-stretch of standard. In fact, there is no convincing basis why we should embrace this standard as a hard and fast rule. There is no doubt that civil disobedience is a self-limiting phenomenon since only a fraction of peoples would have the courage to face the resulting penalties for legal infringements. (Note 94) It is but common sense that everything we do has effects (some intended, others unintended), especially where the means employed are alien to the conventional. Laws especially bad ones cannot therefore immune protesters from punishment. For the most part, protesters are not protected, given that civil disobedience typically involves an illegal activity. (Note 95) Indeed, civil disobedience is always something that can send one to jail. (Note 96) It is one thing to establish that people would be deterred with severe punishment. It is quite another to interpret that anticipation as a rule. As afore-stated, it is not uncommon for civil disobedient to embrace punishment as a tactic for the publicity of the campaign. Those who engage in civil disobedience may deliberately accept the punishment, may be coerced against their will but are actually under no obligation to accept the legal penalty. (Note 97) Both Professors Zinn and Dworkin have come to the conclusion that if the cause is morally justified, then it is morally justified to the very end. (Note 98) To wholeheartedly accept the government or societal injustice would only fuel more energy to foster the prevailing injustice. Protesters who accept punishment signify acceptance of the prevailing system by validating the assumption that we must always obey the law. (Note 99)

\section{Conclusion}

There seems to always be a good deal of distress expressed by those in authority each time the masses or a fraction thereof resolve to civil disobedience. This is graspable given that uprisings habitually threaten the very fabrics of the society. The stories of Antigone, Socrates, Thoreau, Gandhi, King, Malcolm X are certainly familiar to many of us today. They never had an easy or comfortable task. However, the steadfast commitment they invested on respective causes has won them an uncontested historical recognition as distinguished thinkers especially in those societies that they boldly challenged. This is not to suggest that the dust has finally settled on the concept of civil disobedience. Far from that, the notion is still almost as hotly contested as during any historical episode. There can be no denying the fact that situations of dire injustice tend to enjoy more public sympathy today than during any other historical episode. This compassion has however not translated into any universal legal right of civil disobedience in the face of injustice.

\section{Between Ordered Injustice and Ordered Liberty}

Every society is normally faced the threat of unlawful conduct. The normal rule is that all citizens should be law abiding, and dissenters made to pay accordingly for any infringements to the legal system. One thing that all societies, free and authoritarian have in common is the stringent requirement of political obligation to obey laws at all times. This leads us to an important problematic: should law be obeyed even where it protects an evil condition? This paper posits that this requirement must not be qualified as a hard and fast rule. It recognizes that where a society is rooted on unjust fabrics, breaking the law would be both desirable and justified. I do not intend to insinuate that one must resort to civil disobedience each time there is an element of injustice. That is not quite what I am advocating, because I am well aware that all societies at every point in time have deeply entrenched elements of systematic injustice. The only difference is that why some thread a committed path towards justice, others simply struggle to maintain their elitist status quo and or exacerbate the inequality gap.

It also seems to me that in reality, those who first break the law are actually not the resisters but rather those who are bent on defending a brutally, oppressive unjust system. The resistance itself is merely a counteractive response to the blatant denial of justice and the unlawful methods used to degrade, torment and exclude them. When injustice is abundant, social tensions are equally ubiquitous and bound to explode at one point or another. An act of Civil disobedience merely epitomizes those crises in law enforcement. It would seem that arguments insisting on the compulsory observance of laws (political obligation) at all times are used as a tactic rather than genuine respect to the legal order, because they are never backed with a corresponding requirement for laws to be just at all times. If an act contrary to conscience is clearly immoral and the government compels its observance, it would mean the state in question wants citizens to act immorally. (Note 100) Political obligation cannot reasonably be imagined in an imperfect or immoral setting nor should it coexist with an immoral injustice. 
The expectation that a true democracy as "government of the people" is anchored on our "real will", our "true morality" and our "true freedom" is incompatible with any other manifestation that exactly represents false morality. (Note 101)

A civil disobedient is a conscientious law violator and moral idealist who conceives the law as necessarily anchored on morality and his conscience as a higher law. His actions are justified because the code of conduct "is out of harmony with the moral law." (Note 102) The argument is in contradistinction with the political obligation to always obey the law. The bone of contention actually resides between the need to have ordered injustice versus the importance of guaranteeing ordered liberty. (Note 103) When law becomes alien to common sense, its moral rationale too becomes incomprehensible. Those arguing for political obligation are right when they assert that civil disobedience will lead to societal disruptions. This argument must not in any way be seen as contradicting or invalidating the raison-d'être of civil disobedience. It has been observed that freedom is never free. It must be demanded by the oppressed. (Note 104) The consequences of the so-called disruptions can hardly be as the degree of injustice inflicted by ordered injustice. (Note 105)

At various sections of this paper, I have argued that resort to civil disobedience must be exercised with a lot of caution. In short, as much as possible, it should be limited to situations where the provocation for it is extreme. Given that civil disobedience is very dependent on one's good conscience, it follows that there can be no "legal" right to break the law as such. In other words, the right to civil disobedience must be "moral", not legal. (Note 106) It goes without saying that the goals of the campaign must themselves be moral. I cannot end without re-emphasizing the importance of caution for anyone contemplating civil disobedience. Conscience is a treacherous guide. Even Hitler acted according to his conscience. (Note 107) As Thomas Hobbes famously observed, a man may be convinced that God has commanded him to act in a particular way. God may have commanded other men to similar beliefs. Consequently, the man who chooses to disobey the law on principle may be a saint, but he may also be a madman. Whatever he is, his presence makes us painfully aware of our choices. (Note 108)

\section{References}

Abraham Lincoln: His Speeches and Writings, ed. Roy Basler. (1946). (World Publishing Company: Cleveland/New York) at 80-81.

Abraham Lincoln. (1998). The Gettysburg Address, Michael McCurdy (Illustrator) (Sandpiper: New York) 1-36

Ameli T. Valentine. (2002). 'Public Administration in Cameroon' [Unpublished]

Bethune, Lebert. (1969). 'Malcolm X in Europe.' in Malcolm X: The Man and His Times. Ed. John Henrik Clarke. (Macmillan: New York)

Bhikhu parekh. (1991). Gandhi's political Philosophy: A Critical Examination (Macmillan: London) at 127-128

Branham, Robert James. (1995) '"I Was Gone on Debating": Malcolm X's Prison Debates and Public Confrontations' 31 Argumentation \& Advocacy 117-137.

Brian F. Danoff, (2000). 'Lincoln, Machiavelli, and American Political Thought' 30 Presidential Studies Quarterly 290-311

Brian R. Fry. (1996). 'Max Weber and US public administration: the administrator as neutral servant' 2 Journal of Management History 37-46

Charles Evans Whittaker (1965) 'Law and Order' 37 New York State Bar Journal at 397

David Boucher \& Paul Kelly (Eds.). (1994). The Social Contract From Hobbes To Rawls (Routledge: New York/ London/ Toronto)

David Lyons. (1998). 'Moral Judgment, Historical Reality and Civil Disobedience' 27 Philosophy and Public Affairs 31-49

David Spitz. (1954). 'Democracy and the Problem of Civil Disobedience' 48 The American Political Science Review 386-403

Erwin N. Griswold (1968). 'Dissent-1968' 42 Tulane Law Review 726-739

Filler. (1964). Epilogue to John Bach McMaster, History of The United States, 369-370.

First Lincoln-Douglas Debate, (1858) Ottawa, III, August 21, in LINCOLN TREASURY 255

Frank M. Johnson Jr. (1967-1968). 'Civil Disobedience and The Law' 20 University of Florida Law Review $267-277$ 
Francis Olsen. (1983-1984). 'Socrates on Legal Obligation: Legitimation Theory and Civil Disobedience' 18 Georgia Law Review 929-966

Hugo A. Bedau. (1961). 'On Civil Disobedience' 58 American Philosophical Association Eastern Division Symposium (1961) Paper Presented at the Fifty-Eighth Annual Meeting, Atlantic City, N.J., December 27-29, 653-665

Howard Zinn. (2002). Disobedience and Democracy: Nine Fallacies on Law and Order (South End Press:Cambridge/Boston/New York)

Jack Weinstein. (1992-1993). 'Considering Jury Nullification: When May and Should a Jury Reject the Law to Do Justice’ 30 American Criminal Law Review 239-254

James H. Cone. (2001). 'Martin and Malcolm on Nonviolence and Violence' 49 Phylon 173-183

Jesse G. Delia, (2000). 'Rhetoric in the Nazi mind: Hitler's theory of persuasion' 37 Southern Speech Communication Journal (1971) 136-149

Judith Shklar, (1991). American Citizenship: The Quest for Inclusion (Harvard University Press: Cambridge, Massachusetts USA)

Keeton Morris (1964-1965). 'The Morality of Civil Disobedience' 43 Texas Law Review 507-525

Malcolm X. (1964) 'The oppressed are shaking off the shackles' Speech delivered at Oxford Union Society, England, December $3^{\text {rd }}$, 1964.

Mann, Michael. 'Were the Perpetrators of Genocide Ordinary Men or Real Nazis - Results from Fifteen Hundred' 14 Holocaust and Genocide Studies 331-366.

Martin Luther King Jr. (1964). 'Letter From Birmingham Jail' in Why We Can’t Wait (Signet Classic: New York/ London)

Matthew Lippman. (1986-1987) 'Civil Disobedience: The Dictates of Conscience versus the Rule of Law' 26 Washburn Law Journal 233-261

Protz Roger. (1964). 'Millions of Britons See Malcolm X In TV Broadcast of Debate at Oxford' The Militant Journal .

Richard P. Fulkerson. (1979). 'The public letter as a rhetorical form: Structure, logic, and style in king's "letter from Birmingham jail” ' 65 Quarterly Journal of Speech 121-136

Steven R. Schlesinger. (1975-1976). 'Civil Disobedience: The Problem of Selective Obedience to Law' 3 Hastings Constitutional Law Quarterly 947-960

Walter Harding. (1982). The Days of Henry Thoreau: A Biography (Dover: New York)

\section{Notes}

Note 1. David Spitz, 'Democracy and the Problem of Civil Disobedience' 48 The American Political Science Review (1954) 386-403 at 306.

Note 2.Jesse G. Delia,'Rhetoric in the Nazi mind: Hitler's theory of persuasion' 37 Southern Speech Communication Journal (1971) 136-149; Mann, Michael, 'Were the Perpetrators of Genocide Ordinary Men or Real Nazis - Results from Fifteen Hundred' 14 Holocaust and Genocide Studies (2000) 331-366.

Note 3.Ibid.

Note 4.Martin Luther King Jr., 'Letter From Birmingham Jail' in Why We Can't Wait (Signet Classic: New York/ London, 1964) at 72

( Luther's 'Letter From Birmingham Jail' written in response to a statement made by eight white Alabama clergymen on April 12, 1963, titled "A Call For Unity" was first published in June 1963.In 1964, he incorporated the full text in his book: Why We Can't Wait. Consequently, where the letter is quoted, the reference would apply to the version in the book).

Note 5.Luther, 'Letter from Birmingham Jail' at 72.

Note 6.David Spitz, 'Democracy and the Problem of Civil Disobedience' 48 The American Political Science Review (1954) 386-403 at 306.

Note 7. Spitz, 'Democracy and the Problem' at 386; Frank M. Johnson Jr., 'Civil Disobedience and The Law' 20 University of Florida Law Review (1967-1968) 267-277 at 270. 
Note 8.Jack Weinstein, 'Considering Jury Nullification: When May and Should a Jury Reject the Law to Do Justice' 30 American Criminal Law Review (1992-1993) 239-254 at 244.

Note 9. Francis Olsen, 'Socrates on Legal Obligation: Legitimation Theory and Civil Disobedience' 18 Georgia Law Review (1983-1984) 929-966 at 930.

Note 10. Bhikhu parekh, Gandhi's political Philosophy: A Critical Examination (Macmillan: London, 1991) at 127-128. cf. David Lyons, 'Moral Judgment, Historical Reality and Civil Disobedience' 27 Philosophy and Public Affairs (1998) 31-49 at 37-38.

Note 11. Ibid.

Note 12. Lyons, 'Moral Judgment, Historical Reality' at 38.

Note 13.See Walter Harding, The Days of Henry Thoreau: A Biography (Dover: New York, 1982); cf. Lyons, 'Moral Judgment, Historical Reality' at 40.

Note 14.Frank Johnson Jr., 'Civil Disobedience and The Law' at 270.

Note 15.Olsen, 'Socrates on Legal Obligation' at 929.

Note 16. Frank Johnson Jr., 'Civil Disobedience and The Law' at 268.

Note 17. Schlesinger, 'Civil Disobedience' at 947.

Note 18. Keeton Morris, 'The Morality of Civil Disobedience' 43 Texas Law Review (1964-1965) 507-525 at 508.

Note 19. Morris, 'The Morality of Civil Disobedience' at 507, 509.

Note 20. Luther, 'Letter From Birmingham Jail' at 67.

Note 21.Steven R. Schlesinger, 'Civil Disobedience: The Problem of Selective Obedience to Law' 3 Hastings Constitutional Law Quarterly (1975-1976) 947-960 at 947.

Note 22.Luther, 'Letter From Birmingham Jail' at 67.

Note 23.Matthew Lippman, 'Civil Disobedience: The Dictates of Conscience versus the Rule of Law' 26 Washburn Law Journal (1986-1987) 233-261 at 239.

Note 24. Hugo A. Bedau, 'on Civil Disobedience' 58 American Philosophical Association Eastern Division Symposium (1961) Paper Presented at the Fifty-Eighth Annual Meeting, Atlantic City, N.J., December 27-29, 1961 (Oct. 12, 1961) 653-665 at 656.

Note 25. Morris, 'The Morality of Civil Disobedience' at 508.

Note 26.First Lincoln-Douglas Debate, Ottawa, III, August 21, 1858, in LINCOLN TREASURY 255 (Compiled by Hansberger 1950). cf. Frank Johnson Jr., 'Civil Disobedience and The Law' at 267 (see footnote 1).

Note 27.By going to the open, the society as a whole becomes sensitive to wrong, immoral and unjust laws, forcing the government to work towards imminent reforms.

Note 28.Morris, 'The Morality of Civil Disobedience' at 508, 509.

Note 29. Morris, ‘The Morality of Civil Disobedience' at 510.

Note 30. Schlesinger, 'Civil Disobedience' at 948.

Note 31. Lyons, 'Moral Judgment, Historical Reality' at 41.

Note 32. Lyons, 'Moral Judgment, Historical Reality' at 41.

Note 33. See for example, Lyons, 'Moral Judgment, Historical Reality'; Francis olsen, 'Socrates on Legal Obligation: Legitimation Theory and Civil Disobedience' 18 Georgia Law Review (1983-1984) 929-966.

Note 34. Lyons, 'Moral Judgment, Historical Reality' at 40.

Note 35. Schlesinger, 'Civil Disobedience' at 958.

Note 36. Morris, 'The Morality of Civil Disobedience' at 507.

Note 37. The proponents of this theory include Thomas Hobbes, John Locke, Jean Jacques Rousseau and John Rawls.

Note 38. Schlesinger, 'Civil Disobedience' at 950-951.

Note 39. Schlesinger, 'Civil Disobedience’ at 951. 
ote 40. Schlesinger, 'Civil Disobedience' at 951.

Note 41. David Boucher \& Paul Kelly (Eds.), The Social Contract From Hobbes To Rawls (Routledge: New York/ London/ Toronto, 1994) at 86

Note 42. Boucher \& Kelly, The Social Contract From Hobbes To Rawls at 86

Note 43. Boucher \& Kelly, The Social Contract From Hobbes To Rawls at 75

Note 44. Boucher \& Kelly, The Social Contract From Hobbes To Rawls at 120

Note 45. Abraham Lincoln, The Gettysburg Address, Michael McCurdy (Illustrator) (Sandpiper: New York, 1998) $1-36$ at 2.

Note 46. Brian R. Fry, 'Max Weber and US public administration: the administrator as neutral servant' 2 Journal of Management History (1996) 37-46 at 37-39.

Note 47. Frank Johnson Jr., 'Civil Disobedience and The Law' at 275.

Note 48. Schlesinger, 'Civil Disobedience' at 948.

Note 49. Ameli T. Valentine, 'Public Administration in Cameroon' (2002) [Unpublished] at 6.

Note 50. Ameli T. Valentine, 'Public Administration in Cameroon' at 8.

Note 51. Judith Shklar, American Citizenship: The Quest for Inclusion (Harvard University Press: Cambridge, Massachusetts USA, 1991) at 1.

Note 52. Morris, 'The Morality of Civil Disobedience' at 507 citing Filler, Epilogue to John Bach McMaster, History of The United States (1964), 369-370.

Note 53. Ibid at 507, 508.

Note 54. Lyons, 'Moral Judgment, Historical Reality' at 39.

Note 55. Lyons, 'Moral Judgment, Historical Reality' at 39.

Note 56. Frank Johnson Jr., 'Civil Disobedience and The Law' at 271, 275.

Note 57. Frank Johnson Jr., 'Civil Disobedience and The Law' at 271.

Note 58. Morris, 'The Morality of Civil Disobedience' at 512-513.

Note 59s. Olsen, 'Socrates on Legal Obligation' at 930; Morris, 'The Morality of Civil Disobedience' at 512.

Note 60. Schlesinger, 'Civil Disobedience' at 953.

Note 61. Erwin N. Griswold, 'Dissent-1968' 42 Tulane Law Review (1968) 726-739 at 736 [Emphasis added]

Note 62. Lyons, 'Moral Judgment, Historical Reality' at 34.

Note 63. Frank Johnson Jr., 'Civil Disobedience and The Law' at 275-276.

Note 64. Morris, 'The Morality of Civil Disobedience' at 508.

Note 65. Schlesinger, 'Civil Disobedience' at 953.

Note 66. Thomas Jefferson on Politics \& Government, Full speech available online: http://etext.virginia.edu/jefferson/quotations/jeff0500.htm. Last Assessed: 24th May 2010.

Note 67. Charles Evans Whittaker, 'Law and Order' 37 New York State Bar Journal (1965) at 397. cf. Frank Johnson Jr., 'Civil Disobedience and The Law' at 271.

Note 68. Lincoln's address to Young Men's Lyceum of Springfield, Illinois, January 27, 1838; See Brian F. Danoff,, 'Lincoln, Machiavelli, and American Political Thought' 30 Presidential Studies Quarterly (2000) 290-311 at 298. See also Abraham Lincoln: His Speeches and Writings, ed. Roy Basler (World Publishing Company: Cleveland/New York, 1946) at 80-81.

Note 69. Frank Johnson Jr., 'Civil Disobedience and The Law' at 273; Schlesinger, 'Civil Disobedience' at 654; Weinstein, 'Considering Jury Nullification' at 253.

Note 70. Weinstein, 'Considering Jury Nullification' at 240.

Note 71. Luther, 'Letter From Birmingham Jail' at 65.

Note 72. Weinstein, 'Considering Jury Nullification' at 244.

Note 73. Luther, 'Letter From Birmingham Jail' at 72. 
Note 74. Luther, 'Letter From Birmingham Jail' at 66. (King went on to enumerate some of the atrocities inflicted on the black community: "[Birmingham's]... ugly brutality is widely known...Negroes have experienced grossly unjust treatment in the courts. There have been more unresolved bombings of negro homes and churches in Birmingham than any other city in the nation...").

Note 75. Luther, 'Letter From Birmingham Jail' at 72 . While many writers have mostly agreed with these standards, the requirement of willingly accepting the penalty remains a subject of heated debate.

Note 76. Richard P. Fulkerson, 'The public letter as a rhetorical form: Structure, logic, and style in king's "letter from Birmingham jail” ' 65 Quarterly Journal of Speech (1979) 121-136 at 129.

Note 77. cf. Fulkerson, 'The public letter as a rhetorical form' at 129. (For original version, see Luther, 'Letter From Birmingham Jail' at 71.)

Note 78. cf. Fulkerson, 'The public letter as a rhetorical form' at 129. (For original version, see Luther, 'Letter From Birmingham Jail' at 71.)

Note 79. Luther, 'Letter From Birmingham Jail' at 70.

Note 80. James H. Cone, 'Martin and Malcolm on Nonviolence and Violence' 49 Phylon (2001) 173-183 at 173.

Note 81 . See remarks by US President, Barack Obama at the acceptance of the Nobel Peace Prize, Oslo City Hall, December 10, 2009: “...I face the world as it is, and cannot stand idle in the face of threats to the American people. For make no mistake: Evil does exist in the world. A non-violent movement could not have halted Hitler's armies. Negotiations cannot convince al Qaeda's leaders to lay down their arms. To say that force may sometimes be necessary is not a call to cynicism -- it is a recognition of history; the imperfections of man and the limits of reason." (White House Official Release. Available online : http://www.whitehouse.gov/the-press-office/remarks-president-acceptance-nobel-peace-prize ) Last Assessed, June 14th, 2010.

Note 82. Schlesinger, 'Civil Disobedience' at 955.

Note 83. Cone, 'Martin and Malcolm' at 179.

Note 84. Malcolm X, 'The oppressed are shaking off the shackles' Speech delivered at Oxford Union Society, England, December 3rd, 1964. The debate was reportedly televised by most major TV networks, including the British Broadcasting Corporation (BBC) that estimated its audience alone at ten million.

See also Bethune, Lebert. 'Malcolm X in Europe.' in Malcolm X: The Man and His Times. Ed. John Henrik Clarke. (Macmillan: New York, 1969) at 233.

Note 85. Protz Roger, 'Millions of Britons See Malcolm X In TV Broadcast of Debate at Oxford' The Militant Journal 14 December 1964 at 2; See also Branham, Robert James, "I Was Gone on Debating": Malcolm X's Prison Debates and Public Confrontations' 31 Argumentation \& Advocacy (1995) 117-137.

Note 86. Cone, 'Martin and Malcolm' at 180.

Note 87. The American Revolution against the British colonial oppression widely heralded as heroic was a veritable exercise of self-defense. It was not pacific by any measure.

Note 88. Morris, 'The Morality of Civil Disobedience' at 510.

Note 89. Malcolm X, 'The oppressed are shaking off the shackles' speech, op. cit. See also Malcolm X, Malcolm X Speaks, ed. George Breitman (Grove Press: New York, 1965) at 108-113.

Note 90. Malcolm X, 'The oppressed are shaking off the shackles' speech, op. cit. See also Malcolm X, Malcolm X Speaks, ed. George Breitman (Grove Press: New York, 1965) at 113; See also Protz, 'Millions of Britons See Malcolm X' at 2.

Note 91. See for example, Lyons, 'Moral Judgment, Historical Reality'; Francis olsen, 'Socrates on Legal Obligation: Legitimation Theory and Civil Disobedience’ 18 Georgia Law Review (1983-1984) 929-966.

Note 92. Bedau, 'on Civil Disobedience' at 657.

Note 93. See Luther, 'Letter From Birmingham Jail' at 72.

Note 94. Schlesinger, 'Civil Disobedience' at 955.

Note 95. At the epic of the civil rights movement, black students and moderate whites opposing segregation began a campaign known as "freedom rides" which basically was the ridding of interstate buses on a non-segregated basis into the segregated southern States in order to test the Supreme Court decision in Boynton 
v. Virginia (1960). Many of the activists were arrested because the rides violated the local state laws which required segregation of the buses. Many of the buses also came under routine attacks from the Ku Klux Klan (KKK). The police refused to protect the victims or investigate the atrocities on the ground that those violating local laws did so as "outside agitators."

Note 96. Bedau, 'on Civil Disobedience' at 654.

Note 97. Schlesinger, 'Civil Disobedience' at 956 (Explaining the positions of Professors Howard Zinn.and Ronald Dworkin on this issue).

Note 98. Zinn for instance has provided that "If a specific act of civil disobedience is a morally justifiable act of protest, then the jailing of those engaged in that act is immoral and should be opposed, contested to the very end...To accept jail penitently as an accession to the rules is to switch suddenly to a spirit of subservience, to demean the seriousness of the protest." (See Howard Zinn, Disobedience and Democracy: Nine Fallacies on Law and Order (South End Press: Cambridge/Boston/New York, 2002) at 121).

Note 99 Lyons, 'Moral Judgment, Historical Reality' at 32.

Note 100. Spitz, 'Democracy and the Problem of Civil Disobedience' at 400.

Note 101. Spitz, 'Democracy and the Problem of Civil Disobedience' at 400.

Note 102. Luther, 'Letter From Birmingham Jail' at 71.

Note 103. Frank Johnson Jr., 'Civil Disobedience and The Law' at 273.

Note 104. Luther, 'Letter From Birmingham Jail' at 68.

Note 105. As one author has neatly put it: "the dissenter proposes to justify his disobedience by an appeal to the incompatibility between his political circumstances and his moral convictions. Usually, this requires that he be convinced that it would be worse for everyone to suffer the consequences of the objectionable law than it would be for everyone to suffer the consequences of his civil disobedience...." (Bedau, 'on Civil Disobedience' at 659).

Note 106. Frank Johnson Jr., 'Civil Disobedience and The Law' at 276.

Note 107. Lippman, 'Civil Disobedience' at 233.

Note 108. cf. Frank Johnson Jr., 'Civil Disobedience and The Law' at 277 (With emphasis added). 